\title{
CELLULASE AND ITS ROLE IN INDUSTRIES: A REVIEW
}

\author{
Vijay Pratap Singh ${ }^{1}$ and Divya Sharma ${ }^{2 *}$ \\ ${ }^{a}$ Department of Life Sciences \\ IAMR College, Ghaziabad, Uttar Pradesh, India
}

\begin{abstract}
Cellulose is the most abundant polymer present in various agricultural wastes. These wastes can be converted into useful products by degradation of cellulose present inside these wastes. The conversion is catalysed by cellulase enzyme. This review describes the bacterial cellulase enzyme including their classification, isolation, production and applications. In this, we have mentioned the isolation and screening techniques of bacterial cellulase along with some other microbial species, which are having potential of producing cellulase enzyme. It also discusses the submerged and solid-state production of cellulase enzyme along with applications in textile, paper, production of biofuel, food and animal feed industry, oil extraction, brewing, and agriculture. Now a days, industrial enzymes achieved a great place due to their easy production from cheap agricultural wastes together with their magnificent role in above mentioned industries. These features attract the industries, so that they can make their products economically valuable and also improve the protocols accordingly.
\end{abstract}

Keywords: Cellulase; Fermentation; Isolation and screening; Industrial applications; Eco-friendly (agrowastes).

\section{INTRODUCTION}

The most remarkable feature of enzymes is to convert complex and ecological degradative process into more feasible and environmentally friendly form. Detailed knowledge of various enzymes like their occurrence and roles lead to the evolution of novel biological processes. The perpetual utilization of enzymes from several years due to their specificity in industries, metabolism and biochemical processes concomitantly known as "enzyme technology". Cellulase is one of the most popular inducible enzymes synthesized by various microorganisms such as bacteria and fungi. Cellulase enzymes are becoming the main focus of research these days due to their role and applications in various industries. Cellulase enzymes help in the breakdown of cellulose polysaccharides which is present inside the plant cell wall along with xylan and pectin. Cellulose is a glucose polymer of anhydro-Dglucose units linked by 1 , 4- $\beta$-D-glucoside bonds, which makes a major part of plant cell wall. Cellulose and hemicellulose consist nearly $40-60 \%$ of plant cell wall materials (Mccann and Carpita 2008). Cellulose can be converted easily into its monomeric form by biological means i.e. by cellulase enzymes. Different microorganisms have the ability into produce cellulase for the conversion of cellulose polymer (one of the most abundant polymers on earth) to glucose monomer (Saha et al., 2006). So, it is important to develop a cost-effective strategy, which can utilize the low-cost carbon sources such as agricultural wastes (Shanmugapriya et al., 2012).

Cellulase comprises of three different enzymes i.e. endoglucanases, also called 1,4- $\beta$-D-glucan-4glucanohydrolase or carboxymethyl cellulase (EC 3.2.1.4); exoglucanases $1,4-\beta-D-G l u c a n$ cellobiohydrolases (cellobiohydrolases) (EC 3.2.1.91) or 1 , 4- $\beta$-D-oligoglucan cellobiohydrolases (also known as cellodextrinases) (EC 3.2.1.74) and $\beta$-glucosidases or $\beta$-Dglucoside glucohydrolases (EC 3.2.1.21) (Shankar and Isaiarasu 2011). All three enzymes act in consecutive manner to catalyse the cellulose. Various fungal cellulase has been reported in literatures but bacterial cellulase have

*Corresponding author: divya.biotech921@gmail.com 
high growth rate in comparison to fungal form. So, therefore more research has been focussed on bacterial isolate, which can produce high cellulase activity along with high thermo and $\mathrm{pH}$ stability. Bacteria and fungi have been known to produce enzymes freely in solution, but some other microorganisms have also been known to produce cell-bound enzymes with multi-protein complexes known as cellulosomes (Shaikh et al., 2013). Firstly, cellulosome was recognized in thermophilic sporeforming Clostridium thermocellum (Maki et al., 2011). Cellulase production rely on various growth parameters such as inoculum size, $\mathrm{pH}$, temperature, aeration, growth and incubation time (Immanuel et al., 2006). It also depends on several activators and inhibitors (Muhammad et al., 2012). Due to the potential role of cellulase in academic along with research in industries have increased their demand commercially from last several years (Singh et al., 2007). Therefore, there is need to develop new methodology for their screening and production in order to attain their major goal in industries.

So, we can say that cellulose is the most abundant polymer present in various agricultural wastes. These wastes can be converted into useful products by degradation of cellulose present inside these wastes. The conversion is catalysed by cellulase enzyme. This review describes the bacterial cellulase enzyme including their classification, isolation, production and applications. In this we have mentioned the various isolation and screening techniques of bacterial cellulase along with some other microbial species having potential of producing cellulase enzyme. It also discusses the submerged and solid-state production of cellulase enzyme along with applications in textile, paper, production of biofuel, food and animal feed industry, oil extraction, brewing, and agriculture. Now a days, industrial enzymes achieved a great place due to their easy production from cheap agricultural wastes together with their magnificent role in above mentioned industries. These features attract the industries, so that they can make their products economically valuable and also improve the protocols accordingly.

\section{Classification of Cellulase}

Cellulase production from different microorganisms and detailed analysis of cellulosomes helps to classify the cellulase on the basis of their mode of action (Sadhu and Maitri 2013).

\section{Endoglucanases (EC 3.2.1.4)}

Endoglucanses cut at internal bond of cellulose polymer and release the various monosaccharides units of unequal length.

\section{Exoglucanase (EC 3.2.1.91)}

Exoglucanases attacks at the exposed end of cellulose chain produced after the attack of endoglucanse and results in formation of various disaccharides or tri-tetrasaccharide units.

\section{Exoglucanases (EC 3.2.1.74)}

This is another form of exoglucanases, which act on the reducing end of cellulose polysaccharides and produces various disaccharide units.

\section{$\beta$ - Glucosidases (EC 3.2.1.21)}

It cleaves the non-reducing end of cellulose after the attack of exoglucanses and generates several monomeric units.

\section{Mechanism of cellulose degradation}

As it is clear from the action of above-mentioned enzymes that the conversion of cellulose to glucose, involving the attack of endoglucanases and exoglucanases, these two enzymes decreases the length of polymeric cellulose and produces various di-tetra saccharides units. The final step is performed by $\beta$-glucosidase that converts these saccharide units into monomeric glucose units (Hasunuma et al. 2013) as shown in Fig.1.

\section{Cellulase enzyme producing microorganisms}

Various bacterial and fungal strains have been reported in literature due to their ability to produce cellulase (AbdelRaheem and Shearer 2002). Several bacterial species, such as Bacillus, Cellulomonas, Cellovibrio, Micrococcus, Pseudomonas and Sporocytophaga (Immanuel et al. 2006) have been well documented. Various Bacillus species such as, $B$. agardherans, $B$. circulans and B. subtilis have also reported (Li et al. 2006; Korpole et al. 2011; Bai et al. 2012). Bacillus species like B. circulans have ability to produce endoglucanase (Hakamada et al. 2002). Similarly, Bacillus amyoliquefaciens (Lee et al. 2008) and Bacillus thuringiensis (Lin et al. 2012) have been reported to produce cellulase. Some aerobic and anaerobic cellulase producing bacteria are shown in Table (Kuhad et al. 2011).

\section{Screening and Isolation of Bacterial Cellulase}

For the screening of bacterial cellulase, soil samples of different areas have to be collected. Serial dilutions of soil samples were prepared and spread over on the various cellulose nutrient media plates containing $0.5 \%$ peptone, $0.3 \%$ beef extract, $1.5 \%$ agar and $1 \%$ cellulose respectively. The plates will be incubated at $37^{\circ} \mathrm{C}$ for $48 \mathrm{~h}$, after the incubation time period plates were evaluated for the presence of colonies. These colonies are further used for the preparation of replica plates under the same conditions (Varghese et al. 2017). After the growth of bacterial colonies, these plates were submerged with $0.5 \%$ congo red solution and further destained with $1 \mathrm{M} \mathrm{NaCl}$ for 20 minutes and 20-30 minutes respectively. The colonies of cellulase producing bacteria will evaluated by measuring the zone of hydrolysis around the bacterial colonies (Gessesse and Gashe1997). The above-mentioned protocol 
will repeated again to get the pure cellulase producing colonies. This is the quantitative screening, where the bacterial colonies were utilised for the production of cellulase enzymes under different physiological conditions and various physiochemical parameters are also optimized in order to get the maximum production of enzyme.

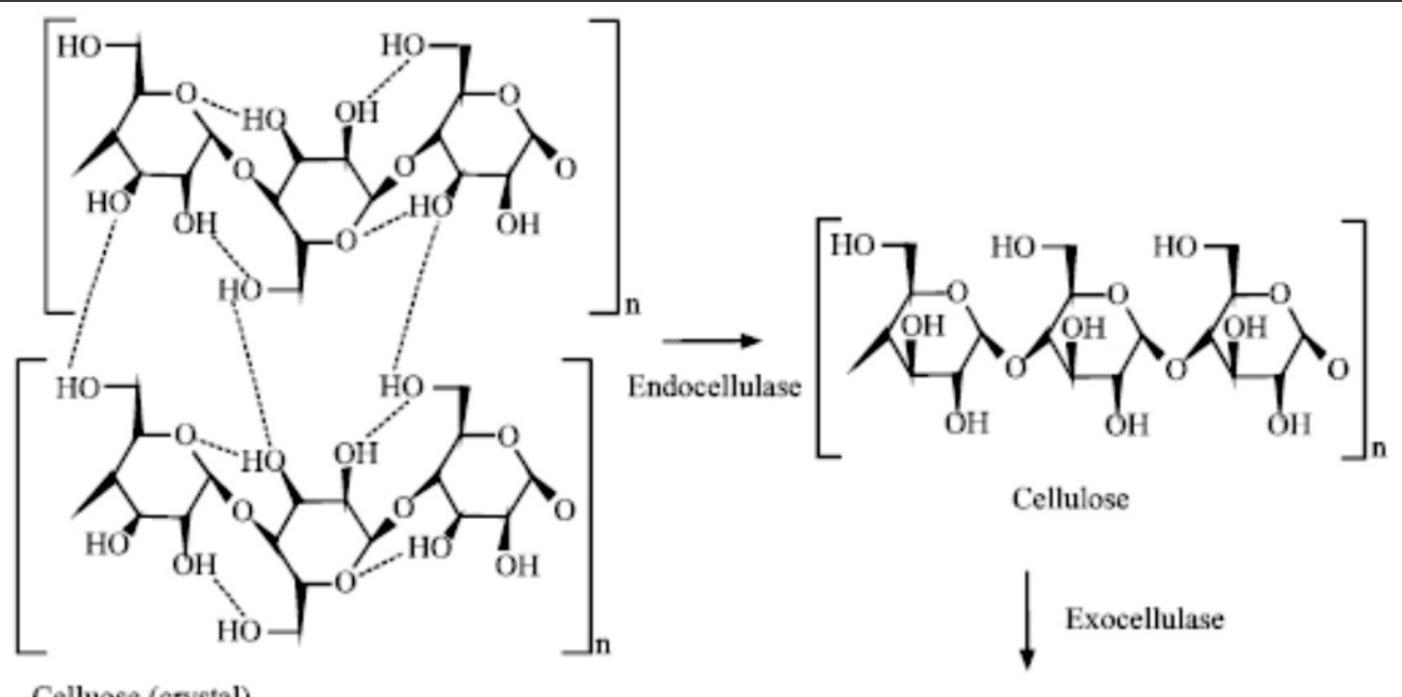

Celluose (crystal)

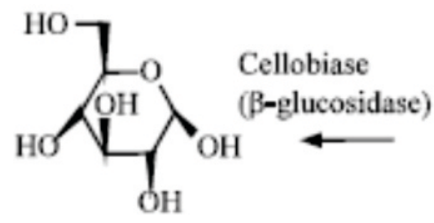

Glucose

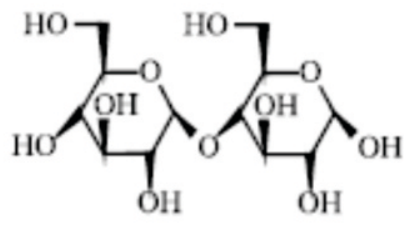

Cellobiose or Cellotetrose

Fig. 1: Mechanism of cellulase enzyme.

Table 1: Some cellulase producing Bacteria.

\begin{tabular}{|l|}
\hline Cellulase Producing Bacteria \\
\hline Aerobic bacteria \\
\hline Acinetobacter junii; A. amitratus; Acidothermus \\
cellulolyticus; Anoxybacillus sp.; Bacillus subtilis; B. \\
pumilus; B.amyloliquefaciens; B. licheniformis; B. \\
circulan; B. flexus; Bacteriodes sp.; Cellulomonas \\
biazotea; Cellvibrio gilvus;Eubacterium cellulosolvens; \\
Geobacillus sp.; Microbispora bispora; Paenibacillus \\
curdlanolyticus; Pseudomonascellulosa; Salinivibrio sp.; \\
Rhodothermus marinus
\end{tabular}

\section{Cellulase Production using Fermentation}

Production of enzymes using fermentation is one of the most popular method. Fermentation involves the use of microorganisms for converting the complex polysaccharides into their respective monomeric form. Fermentation techniques used for the cultivation of enzymes comprises of two different form (Table 2) i.e Submerged fermentation $(\mathrm{SmF})$ and Solid-state

\section{Anaerobic bacteria}

Acetivibrio cellulolyticus; Butyrivibrio fibrisolvens; Clostridium thermocellum; C. cellulolyticum; C. acetobutylium;C.papyrosolvens; Fibrobacter succinogenes; Ruminococcus albus

fermentation (SSF). Optimum growth conditions required by several microorganisms are not same, every microbe needs some specific growth parameters for maximum enzyme production. These conditions have to be optimized for attaining maximum enzyme titre and this is achieved by either 'one-variable-at-a-time' or statistical approach (Pandiyan et al.2014). 


\section{Submerged Fermentation (SmF)}

SmF uses a liquid medium for growing the microbes. All the essential nutrients were dissolved in this liquid broth for the production of enzyme by the microbe. It is the easy method with simple handling. This method is widely used for purification purpose (Subramaniyam et al. 2012).

\section{Solid-State Fermentation (SSF)}

SSF uses solid substrates such as wheat bran, bagasse, paddy straw and other agricultural wastes with very low moisture content. All the substrates used in this fermentation can be reused again (Babu and Satyanarayana 1996).

\section{Applications of Cellulase}

Initially cellulase enzymes were used for biological conversion of biomass and various cellulose containing materials, which are thought to be the waste of agricultural residue. But now, these waste materials are used for maximal production of cellulase enzyme for their utilization in textile industry, paper industry, food and animal feed industry, oil extraction, brewing, agriculture and biofuel production.

\section{Textile industry}

Cellulase have been used in textile industries for the biostoning of various denim clothes to produce softness and faded look to the jeans. During this process, cellulase break down the small fibers and produces a well-furnished fabric. Conventionally, pumice stone are used for this purpose. The advantage of using cellulase over pumice stone is less damage to the fiber and also environmentally safe (Saranraj et al. 2012).

\section{Paper and Pulp industry}

Cellulase alone or in combination with xylanase have been used for biopulping or biobleaching to produce a paper with improved physicochemical properties such as burst factor, tear factor, tensile strength and pulp freeness. The use of enzyme also helps to reduce the amount of toxic chemicals used for bleaching. Cellulase also used for deinking of paper by partial hydrolysis of carbohydrate molecules present in paper (Kuhad et al. 2010).

\section{Food and Animal Feed Industry}

Cellulases have been used widely in food and feed industries. In food industries cellulase is used for production of fruit and vegetable juices. It was done by enzymatic extraction and clarification of juices. In brewery they are also used for the improvement of barley malting.

Table 2: Production of bacterial cellulase enzyme under different fermentation conditions.

\begin{tabular}{|c|c|c|c|}
\hline Bacterial sp. & Substrate used & Fermentation process & References \\
\hline Bacillus sp. AC-1 & CMC & $\mathrm{SmF}$ & Li et al., 2006 \\
\hline $\begin{array}{l}\text { Anoxybacillus flavithermus } \\
\mathrm{EHP}^{2}\end{array}$ & CMC & $\mathrm{SmF}$ & Ibrahim and Ahmed 2007 \\
\hline Cellulomonas cellulans & Paddy straw & $\mathrm{SmF}$ & Mishra et al., 2007 \\
\hline Clostridium thermocellum & Cellulose \& paper pulp & SSF and SmF & Zhuang et al., 2007 \\
\hline Bacillus amyloliquefaciens & Rice hull & $\mathrm{SmF}$ & Lee et al., 2008 \\
\hline Bacillus sp. NZ & Agricultural residues & SSF & $\begin{array}{l}\text { Nizamudeen and } \\
\text { Bajaj } 2009\end{array}$ \\
\hline B. subtilis $\mathrm{KO}$ & Molasses & $\mathrm{SmF}$ & Shabeb et al., 2010 \\
\hline Anoxybacillus sp.527 & Crystalline cellulose & $\mathrm{SmF}$ & Liang et al., 2010 \\
\hline B. subtilis A-53 & Rice bran & SmF & Lee et al., 2010 \\
\hline Bacillus sp. LFC & CMC & SmF & Korpole et al., 2011 \\
\hline B. subtilis & CMC & $\mathrm{SmF}$ & Deka et al., 2011 \\
\hline $\begin{array}{l}\text { Microbacterium sp. } \\
\text { MTCC } 10047\end{array}$ & CMC & $\mathrm{SmF}$ & Sadhu et al., 2011 \\
\hline B. cereus & Palm Kernel Cake & SSF & Lah et al., 2012 \\
\hline $\begin{array}{l}\text { B. licheniformis MVS1 } \\
\text { and MVS3 }\end{array}$ & CMC, Filter paper & SSF & $\begin{array}{l}\text { Acharya and Chaudhary } \\
2012\end{array}$ \\
\hline Bacillus subtilis BS05 & Sugarcane baggase & $\mathrm{SmF}$ & Irfan et al., 2012 \\
\hline
\end{tabular}




\begin{tabular}{|l|l|l|l|}
\hline $\begin{array}{l}\text { Bacillus amyloliquefaciens } \\
\text { SS35 }\end{array}$ & CMC & SmF & Singh et al., 2014 \\
\hline Bacillus sp. SMIA-2 & $\begin{array}{l}\text { Sugarcane bagasse \& } \\
\text { corn steep liquor }\end{array}$ & SmF & Ladeira et al., 2015 \\
\hline $\begin{array}{l}\text { Brucella and } \\
\text { B. licheniformis }\end{array}$ & Maltose and CMC & SmF & Behera et al., 2016 \\
\hline B. licheniformis RT-17 & Sugarcane bagasse & SmF & Tariq et al., 2018 \\
\hline $\begin{array}{l}\text { Paenibacillus polymyxa } \\
\text { ND24 }\end{array}$ & Sugarcane bagasse & SmF & Bohra et al., 2018 \\
\hline
\end{tabular}

Cellulases along with other enzymes have been also used to improve the nutritional value of forages used as animal feed. This is done by the pre-treatment of agricultural fodder and grain feed by removing antinutritional substances (Imran et al. 2016).

\section{Oil Extraction}

Cellulase have been employed for extraction and clarification of olive oil. Use of enzyme increases the amount and antioxidants of oil. Enzyme treatment also decreases the rancidity and viscosity of the oil (Kuhad et al. 2010).

\section{Brewing Industry}

Microbial enzymes help in the fermentation process of several beverages such as beers and wines. Enzyme treatment increases the quality and final quantity off mentation products. An improved cocktail of enzymes like cellulase with pectinase can be used to enhance the production of brewing industries (Bamforth 2009).

\section{Agriculture industry}

Enzymes also have potential applications in agricultural industries for increasing the crop growth along with treatment of various crop diseases. Cellulases improve the fertility of soil. Various agricultural residues such as addition of straw into soil have the capability to improve the quality of soil and decreases the need of fertilizers (Escobar and Hue 2008). So, cellulase can be used for rapid decaying of straw to increase the quality of soil (Han and He 2010).

\section{Production of Biofuel}

Production of various biofuels such as bioethanol and biobutanol, is the only solution to decrease the use of various non-renewable fossil fuels. These fossils produce lot of problems in the environment. Bioethanol can be produced by direct fermentation of simple sugars (called first-generation ethanol) or from saccharification of complex sugars to simple ones, followed by fermentation (called second-generation ethanol). Use of agrowastes such as sugarcane bagasse, corncob, cashew apple bagasse, rice straw, banana stem, pineapple peel for bioethanol production make these wastes valuable and also don't tamper our environment (Siqueira et al. 2020).

\section{CONCLUSION}

The main idea for bioprocessing of agroresidues is entirely depends upon cellulase and cellulase producing microorganisms. Commercially, cellulase enzymes are produced worldwide and are also being utilised in food, animal feed, agriculture, paper, and textile industrial applications. Enhancement in cellulase enzyme titre using novel biotechnological techniques such as protein or metabolic engineering will make the future of enzymebased industries along with production of thermostable or $\mathrm{pH}$ stable cellulase enzymes.

\section{ACKNOWLEDGEMENT}

The authors gratefully acknowledge the IAMR (Institute of Applied Medicines and Research) college, Ghaziabad, Uttar Pradesh for supporting the research.

\section{REFERENCES}

1. Abdel-Rahee A., Shearer C.A. (2002) Extracellular enzyme production by freshwater ascomycetes. Fungal Divers 11:1-19.

2. Acharya S., Chaudhary A. (2012) Optimization of fermentation conditions for cellulases production by Bacillus licheniformis MVS1 and Bacillus sp. MVS3 isolated from Indian hot spring. Braz Arch BiolTechnol 55:497-503.

3. Babu K.R., Satyanarayana T. (1996) Production of bacterial enzymes by solid state fermentation. J Sci Ind Res 55:464-467.

4. Bai S., Kumar M.R., Kumar D.J.M,. Balashanmugam P., Balakumaran M.D., Kalaichelvan P.T. (2012) Cellulase production by Bacillus subtilis isolated from cow dung. Arch Appl Sci Res 4(1):269-279. 
5. Bamforth C.W. (2009) "Current perspectives on the role of enzymes in brewing,” J Cereal Sci 3:53-357.

6. Behera BC, Mishra RR, Santosh KS, Dutt SK, Thatoi H. (2016) Cellulase from Bacillus licheniformis and Brucella sp. isolated from mangrove soils of Mahanadi river delta, Odisha, India. Biocatal Biotransform1-10.

7. Bohra V., Tikariha H., Dafale N. A. (2018) Genomically defined Paenibacillus polymyxa nd24for efficient cellulase production utilizing sugarcane bagasse as a substrate. Appl Biochem Biotechnol.

8. Deka D., Bhargavi P., Sharma A., Goyal D., Jawed M., Goyal A. (2011). Enhancement of cellulase activity from a new strain of Bacillus subtilis by medium optimization and analysis with various cellulosic substrates. Enz Res doi: 10.4061/2011/ 151656.

9. Escobar M.E.O., Hue N.V. (2008). “Temporal changes of selected chemical properties in three manure-amended soils of Hawaii”. Bioresource Technol 99(18):8649-8654.

10. Gessesse A., Gashe B.A. (1997) Production of alkaline xylanase by an alkaliphilic Bacillus sp. isolated from an alkaline soda lake. J Appl Microbiol 83:402-406.

11. Hakamada Y, Endo K, Takizawa S, Kobayashi T, Shirai T., Yamane T., Ito S. (2002) Enzymatic properties, crystallization, and deduced amino acid sequence of an alkaline endoglucanase from Bacillus circulans. Biochim Biophys Actal570:174-180.

12. Han W., He M. (2010) “The application of exogenous cellulase to improve soil fertility and plant growth due to acceleration of straw decomposition," Bioresource Technol 101(10):3724-3731.

13. Hasunuma T., Okazaki F., Okai N., Hara K.Y., Ishii J., Kondo A. (2013). A review of enzymes and microbes for lignocellulosic biorefinery and the possibility of their application to consolidated bioprocessing technology, Bioresour Technol 135:513-522.

14. Ibrahim ASS, Ahmed IED. (2007) Isolation and identification of new cellulases producing thermophilic bacteria from an Egyptian hot spring and some properties of the crude enzyme. Aust J Bas Appl Sci1(4):473-478.

15. Immanuel G., Dhanusha R., Prema P., Palavesam (2006) Effect of different growth parameters on endoglucanase enzyme activity by bacteria isolated from coir retting effluents of estuarine environment. Int J. Environ Sci Tech 3(1):25-34.

16. Imran M., Anwar Z., Irshad M., Asad M.J., Ashfaq H. (2016) Cellulase Production from Species of Fungi and Bacteria from Agricultural Wastes and Its Utilization in Industry: A Review. Adv Enzyme Res 4:44-55.

17. Irfan M., Nadeem M., Syed Q., Baig S. (2012) Effect of medium composition on xylanase production by Bacillus subtilis using various agricultural wastes. Am Eurasian J Agric Environ Sci 12(5):561-565.

18. Korpole S., Sharma R., Verma D. (2011) Characterization and phylogenetic diversity of carboxymethyl cellulase producing Bacillus species from a landfill ecosystem. Ind J Microbiol 51(4):531535.

19. Kuhad R.C., Gupta R., Singh A. (2011). Microbial cellulases and their industrial applications. Enzyme Res doi:10.4061/2011/280696.

20. Kuhad R.C., Mehta G., Gupta R., Sharma K.K. (2010). "Fed batch enzymatic saccharification of newspaper cellulosics improves the sugar content in the hydrolysates and eventually the ethanol fermentation by Saccharomyces cerevisiae,” Biomass Bioenerg 34(8):189-119.

21. Ladeira S.A., Andreia E.C., Delatorre B., Barbosa J.B., Martins M.L.L. (2015). Cellulase production by thermophilic Bacillus sp. SMIA-2 and its detergent compatibility. Electron J Biotechnol 18:110-115.

22. Lah NT, Rahman NB, Nama MB (2012). Cellulase activity and glucose production by Bacillus cereus monoculture and co-culture utilizing palm kernel cake (PKC) under solid state fermentation. Int Conf Envt Ene Biotechnol 33:172-177.

23. Lee YJ, Kim BK, Lee BH, Jo KI, Lee NK, Chung CH, Lee YC, Lee JW (2008). Purification and characterization of cellulase produced by Bacillus amyoliquefaciens DL-3 utilizing rice hull. Bioresour Technol 99(2):378-386.

24. Lee B.H., Kim B.K., Lee Y.J., Chung C.H., Lee J.W. (2010). Industrial scale of optimization for the production of carboxymethyl cellulase from rice bran by a marine bacterium Bacillus subtilis subsp. subtilis A-53. Enz Microb Technol 46:38-42.

25. Li YH, Ding M, Wan J, Xu GJ, Zhao F (2006). A novel thermoacidic endoglucanase, Ba-EGA, from a new cellulose-degrading bacterium, Bacillus sp. AC1. Appl Microbiol Biotechnol 70:430-436. 
26. Liang Y, Feng Z, Yesuf J, Blackburn JW (2010). Optimization of growth medium and enzyme assay conditions for crude cellulases produced by a novel thermophilic and cellulolytic bacterium, Anoxybacillus sp. 527. Appl Biochem Biotechnol 160:1841-1852.

27. Lin L, Kan X, Yan H, Wang D. (2012). Characterization of extracellular cellulose degrading enzymes from Bacillus thuringiensis strains. Elect $J$ Biotechnol 15(3):310-317.

28. Maki ML, Broere M, Leung KT, Qin W. (2011). Characterization of some efficient cellulase producing bacteria isolated from paper mill sludges and organic fertilizers. Int J Biochem Mol Biol 2(2):146-154.

29. Mccann M.C., Carpita N. C. (2008). Designing the deconstruction of plant cell walls. Curr Opin Plant Biol 11:314-320.

30. Mishra BK, Pandey AK, Lata (2007). Lignocellulolytic enzyme production from submerged fermentation of paddy straw. Ind J Microbiol 47:176179.

31. MuhammadI, Safdar A, Quratulain S, Muhammad N. (2012). Isolation and screening of cellulolytic bacteria from soil and optimization of cellulase production and activity. Turk J. Biochem 37(3):287-293.

32. Nizamudeen S, Bajaj B.K. (2009). A novel thermoalkalitolerant endoglucanase production using costeffective agricultural residues as substrates by a newly isolated Bacillus sp. NZ. Food Technol Biotechnol 47(4):435-440.

33. Pandiyan K, Tiwari R, SinghS, Nain PKS, Rana S, Arora A, Singh SB, Nain L (2014). Optimization of enzymatic saccharification of alkali pretreated Parthenium sp. using response surface methodology. Enz Res doi: 10.1155/2014/764898.

34. Sadhu S, Saha P, Mayilraj S, Maiti TK (2011) Lactose-enhanced cellulase production by Microbacterium sp. isolated from feacal matter of zebra (Equus zebra). CurrMicrobiol 62:1050-1055.

35. Sadhu S, Maiti TK (2013) Cellulase production by bacteria: a review. Br Microbiol Res J 3(3):235-258.

36. Saha S, Roy RN, Sen SK, Ray AK (2006) Characterization of cellulase-producing bacteria from the digestive tract of tilapia, Oreochromismossambica (Peters) and grasscarp, Ctenopharyngodonidella (Valenciennes). Aquac Res 37(4):380-388.
37. Saranraj P., Stella D., Reetha D. (2012) Microbial cellulases and its applictions: a review. Int J Biochem Biotech Sci 1:1-12.

38. Shabeb MSA, Younis MAM, Hezayen FF, NourEldein MA (2010) Production of cellulase in low-cost medium by Bacillus subtilis KO strain. WAppl Sci J 8(1):35-42.

39. Shaikh NM, Patel AA, Mehta SA, Patel, ND (2013) Isolation and screening of cellulolytic bacteria inhabiting different environment and optimization of cellulase production. Univers JEnviron Res Technol 3(1):39-49.

40. Shankar T., Isaiarasu L. (2011) Cellulase production by Bacillus pumilus EWBCM1 under varying cultural conditions. Middle-East JSci Res 8(1):40-45.

41. Shanmugapriya K, Saravana PS, Krishnapriya MM, Mythili A, Joseph S (2012) Isolation, screening and partial purification of cellulase from cellulase producing bacteria. Int J Adv Biotechnol Res 3(1):509514.

42. Singh A, Kuhad RC, Ward OP (2007) "Industrial application of microbial cellulases,” in Lignocellulose Biotechnologgy: Future Prospects345-358, I. K. International Publishing House, New Delhi, India.

43. Singh S, Moholkar VS, Goyal A. (2014) Optimization of carboxymethylcellulase production from Bacillus amyloliquefaciens SS35. 3 Biotech 4(4):411-424.

44. Siqueira JGW, Rodrigues C, Vandenberghe LPDS, Woiciechowski AL, Soccol CR (2020) Current advances in on-site cellulase production and application on lignocellulosic biomass conversion to biofuels: Areview. Biomass Bioenerg 132.

45. Subramaniyam R., Vimala R. (2012) Solid state and submerged fermentation for the production of bioactive substances: A comparative study. Int J Sci Nature 3(3):480-486.

46. Tariq R, Ansari I, Qadir F, Ahmed A, Shariq M, Zafar U, AhmadA, Khan SA, Sohail M (2018) Optimization of endoglucanase production from thermophilic strain of Bacillus licheniformis RT-17 and its application for saccharification of sugarcane bagasse. Pak J Bot 50(2):807-816.

47. Varghese LM, Agrawal S, Sharma D, Mandhan RP, Mahajan R (2017) Cost-effective screening and isolation of xylano-cellulolytic positive microbes from termite gut and termitarium. 3 Biotech7:108.

48. Zhuang J, Marchant MA, Nokes SE, Strobel HJ (2007) Economic analysis ofcellulase production methods for bio-ethanol. Appl Eng Agr 23(5):679-687. 